\title{
35. XRF ANALYSES OF VOLCANIC ROCKS FROM LEG 152 BY LABORATORIES IN EDINBURGH AND COPENHAGEN: IMPLICATIONS FOR THE MOBILITY OF YTTRIUM AND OTHER ELEMENTS DURING ALTERATION ${ }^{1}$
}

\author{
Lotte Melchior Larsen, ${ }^{2}$ J. Godfrey Fitton, ${ }^{3}$ John C. Bailey, ${ }^{4}$ and Jørgen Kystol ${ }^{2}$
}

\begin{abstract}
Neighboring (parallel) samples from 72 lava flows, splits of identical samples from five lava flows, and splits of 10 shipboard powders from Ocean Drilling Program Leg 152 were analyzed by X-ray fluorescence (XRF) in both Edinburgh and Copenhagen. The agreement between the two data sets is very good, although systematic differences are apparent in some cases. Correlation between the results for the identical powders is very high. Correlation between the results for the parallel samples is somewhat lower, mainly because of element redistribution during secondary alteration, but also due to primary lava inhomogeneity. The elements show differences in the degree of scatter due to alteration, with $\mathrm{K}, \mathrm{Rb}$, and $\mathrm{Ba}$ being the most mobile, and $\mathrm{Si}, \mathrm{Sc}, \mathrm{Al}, \mathrm{Fe}, \mathrm{Zn}, \mathrm{V}$, and $\mathrm{Nb}$ the least mobile. Y is immobile in the Site 917 lavas but distinctly mobile in the Site 918 lavas where it is both leached and precipitated locally. The mobility of $\mathrm{Y}$ is related to secondary breakdown of clinopyroxene at Site 918, in contrast to Site 917 where the clinopyroxene is generally fresh. The hydrothermal alteration conditions at the two sites appear to have been different.
\end{abstract}

\section{INTRODUCTION}

During Ocean Drilling Program (ODP) Leg 152 to the southeast Greenland Margin, a succession of subaerial lava flows was drilled. The lava flows are part of the thick submerged seaward-dipping reflector sequence (SDRS) along the margin. The lavas were cored at Sites 915, 917, and 918 and were sampled for geochemical analysis, mainly X-ray fluorescence spectrometry (XRF), in both Edinburgh and Copenhagen. This paper compares the results from the different laboratories. Moreover, the analysis of both identical and nonidentical powders from the same lava units illustrates the effects of primary compositional variability and secondary alteration processes in the volcanic successions.

\section{SAMPLING AND SAMPLE TREATMENT}

From each of 72 lava flows two separate (parallel) samples were taken, whereas single samples from each of five lava flows were shared. Furthermore, splits of 10 powders prepared on the ship were analyzed for trace elements in both Edinburgh and Copenhagen.

In 46 lavas, the parallel samples were taken within less than $10 \mathrm{~cm}$ from each other, and often in direct contact. In 16 lavas, the samples were taken within $10 \mathrm{~cm}$ to $1 \mathrm{~m}$ from each other, and in 10 lavas the samples were taken more than $1 \mathrm{~m}$ apart, the maximum distance being $18.3 \mathrm{~m}$ in a 55-m-thick lava flow (Unit 917-52). The results show no dependence on the distance between the parallel samples.

The data sets from Edinburgh and Copenhagen are published in Fitton et al. (Chap. 28, this volume) and L.M. Larsen et al. (this volume), respectively. The analytical procedures used in Edinburgh and Copenhagen are very similar, major elements being determined on

${ }^{1}$ Saunders, A.D., Larsen, H.C., and Wise, S.W., Jr. (Eds.), 1998. Proc. ODP, Sci. Results, 152: College Station, TX (Ocean Drilling Program).

${ }^{2}$ Geological Survey of Denmark and Greenland, and Danish Lithosphere Centre, Thoravej 8, DK-2400 Kobenhavn K, Denmark. lml@geus.dk

${ }^{3}$ Department of Geology and Geophysics, Grant Institute, University of Edinburgh, West Mains Road, Edinburgh EH9 3JW, United Kingdom.

${ }^{4}$ Institute of Geology, University of Copenhagen, Oster Voldgade 10, DK-1350 Kobenhavn K, Denmark. fused glass discs and trace elements on pressed powder pellets. The major differences are as follows. (1) The Edinburgh samples were crushed in an agate Tema barrel, whereas the Copenhagen samples were crushed in a tungsten carbide ball mill. (2) The Edinburgh glass discs are made with lithium tetraborate and a sample:flux ratio of 1:5, whereas the Copenhagen glass discs are made with sodium tetraborate and a sample:flux ratio of $1: 7$, with $\mathrm{Na}_{2} \mathrm{O}$ determined by atomic absorption spectrometry (AAS). (3) In Edinburgh, the major elements are calibrated on natural rock standards, whereas in Copenhagen, the major elements are calibrated on synthetic standards.

\section{LABORATORY COMPARISON}

In general, the agreement between the two data sets is very good, as shown by the data plots (Fig. 1) and the correlation coefficients and regression line slopes (Table 1). For most elements the results plot close to a 1:1 line with very high correlation coefficients for the identical powders $(>0.99)$ and somewhat lower correlation coefficients for the parallel powders from the same lava flow units. Differences due to calibration effects are noted for $\mathrm{Ba}, \mathrm{La}, \mathrm{Nb}$, and $\mathrm{Sc}$, with line slopes for identical powders of $0.89,0.83,1.07$, and 0.81 , respectively. Differences due to blank or background effects are noted for $\mathrm{P}_{2} \mathrm{O}_{5}$ and $\mathrm{Zn}$. The results for Co (Fig. 1) show that the tungsten carbide ball mill used for crushing the samples in Copenhagen has introduced 5-10 ppm Co in the samples.

Results for the parallel powders plot along similar regression lines to the results for the identical powders, but the scatter is larger (smaller correlation coefficients, Table 1). The larger scatter is caused by a combination of primary heterogeneity in lava compositions and element redistribution during secondary alteration processes.

\section{LAVA HETEROGENEITY}

Primary heterogeneity was evident during sampling of two lava flows. Unit $917-21$ is a very olivine-rich lava, and the two samples contained visually different proportions of olivine. Unit 917-54 is a dacite with frequent inclusions of basalt. The parallel samples from these two lava flows show significant compositional differences, and they have been omitted from the calculations discussed below. Pri-

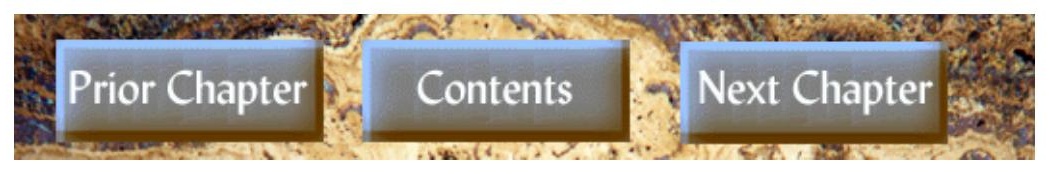



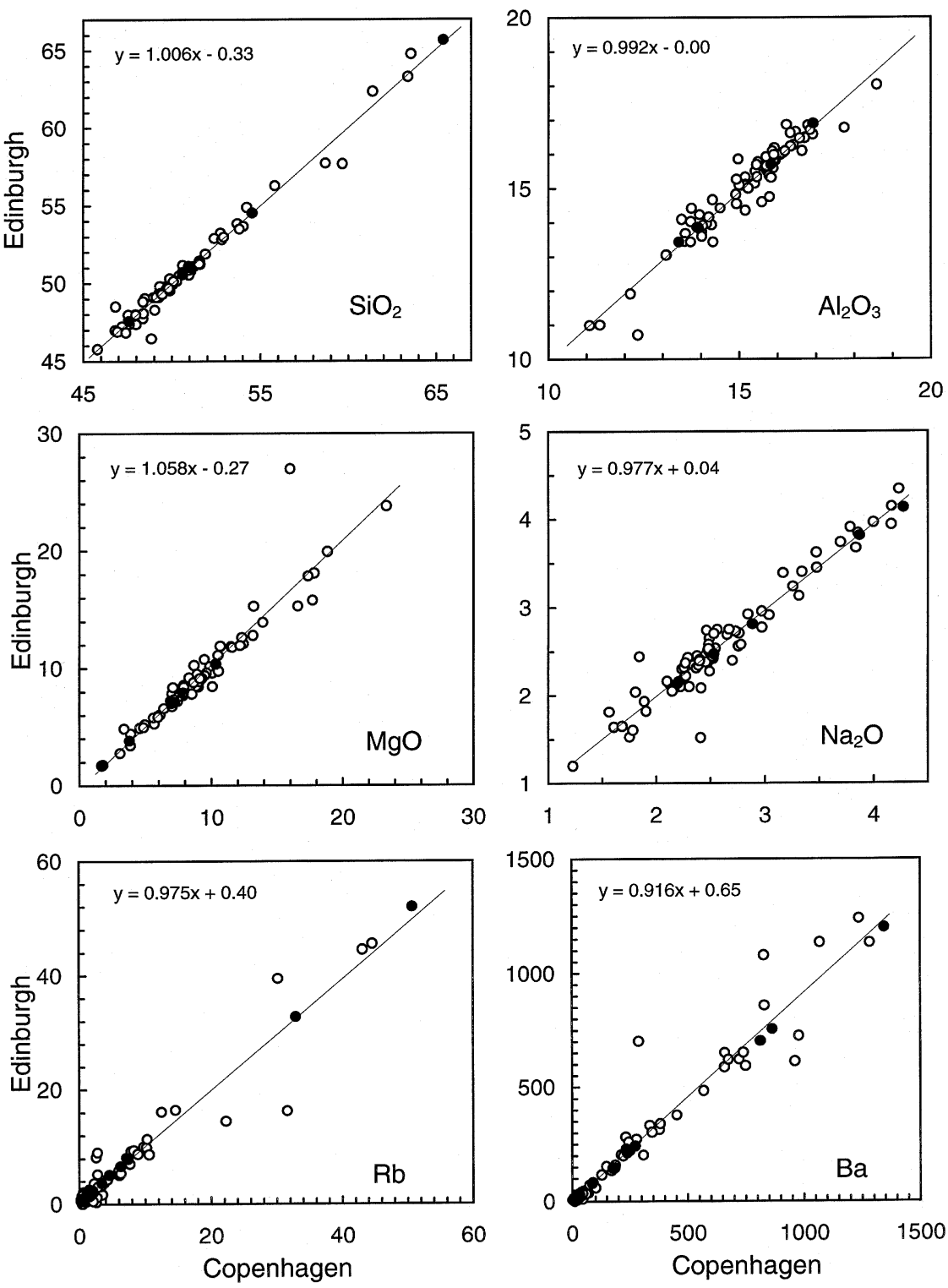

Figure 1. XRF analyses of Leg 152 lavas performed in Edinburgh and Copenhagen. Solid circles $=$ analyses of identical powders; open circles $=$ analyses of parallel samples from the same lava flows. The regression lines and equations include both groups. Note that the identical powders show a smaller scatter around the regression lines than do the parallel powders. Values in weight percent for the major element oxides and parts per million for the trace elements.

comm., 1996). Zeolites are abundant in Site 917 Upper and Lower

mary heterogeneity is probably also present in other sample pairs, but it is not possible to distinguish such pairs on an objective basis.

\section{ALTERATION}

The samples represent the freshest and most massive, nonvesiculated parts of the flows. However, the degree of alteration of the samples varies from slight to high. The interstitial glass has been altered to clay and sometimes zeolites in all the samples, and in many samples the olivine is also completely altered to clay and opaque oxides. In the most altered samples, especially in the Site 917 Upper Series, the plagioclase is partly broken down. At Site 918, plagioclase is usually relatively well preserved, whereas the clinopyroxene may be extensively broken down (A. Demant, pers. comm., 1996). Modal analyses in Larsen, Saunders, Clift, et al. (1994) show clay contents frequently in the range 10\%-30\% for Site 917, and around 10\% for Site 918. Olivine is replaced by saponitic clay, whereas the matrix is replaced by mixed-layer chlorite/smectite in Site 917 Upper and Lower Series, and by mixed-layer celadonite/smectite in Site 917 Middle Series and Site 918 (Demant et al., this volume, and A. Demant, pers.
Series, rare in Site 917 Middle Series, and almost totally absent in Site 918 (Larsen, Saunders, Clift, et al., 1994). They are identified as chabazite, heulandite-group, thomsonite, analcite, and natrolite (Demant et al., this volume). The alteration mineral association at both sites corresponds to low temperature zeolite facies.

Several elements are known to be affected by such secondary alteration processes, and for these elements alteration is considered the main reason for the larger data scatter for the parallel powders seen in Figure 1 and Table 1.

The correlation coefficients shown in Table 1 are dependent on the compositional range of a given element. Zinc, for example, has a restricted compositional range (70-150 $\mathrm{ppm})$, which leads to a relatively poor correlation coefficient even for identical powders (0.977). A more independent measure of the data scatter around the regression line is the standard error, which is a measure of the average distance of the points from the regression line. The relative error is the standard error expressed as a percentage of the average concentration of an element.

Figure 2 and Table 2 show the differences in relative errors between the parallel powders and the identical powders. This is a quan- 

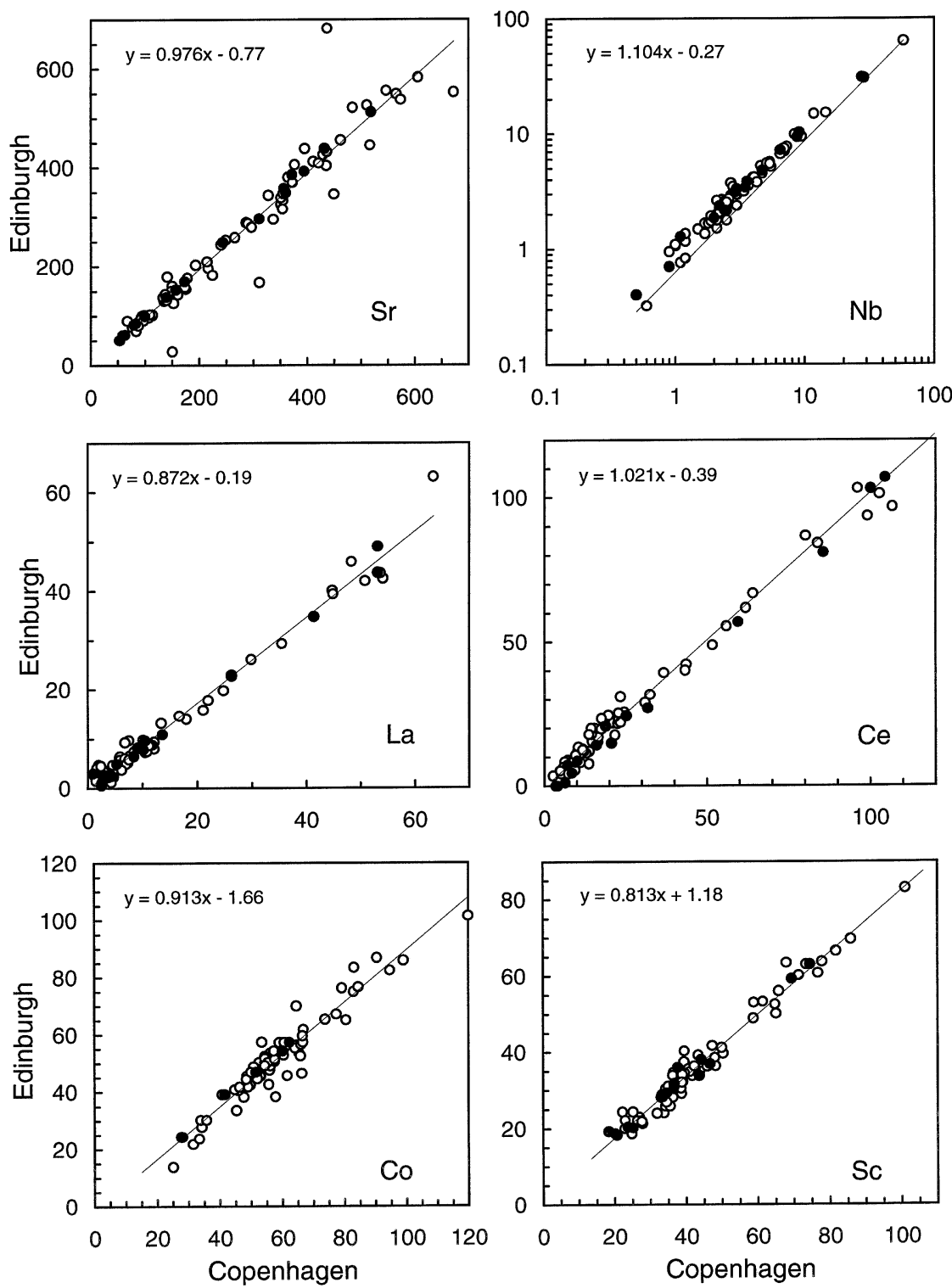

Figure 1 (continued).

titative expression of the data scatter around the regression lines shown in Figure 1, and it is independent of calibration differences (line slopes) for some elements noted earlier. The elements are arranged in order of increasing data scatter, excluding Site 918 lavas for reasons given below. The main reason for the data scatter is considered to be element redistribution during alteration, although a component of primary lava inhomogeneity is probably also present, as noted above.

The element succession in Figure 2, from left to right, is a measure of the relative mobility of the elements. $\mathrm{K}, \mathrm{Ba}$, and $\mathrm{Rb}$, known to be highly mobile, have the largest relative scatters $(25 \%-44 \%) . \mathrm{Sr}, \mathrm{Cu}$, $\mathrm{Ni}, \mathrm{Mn}, \mathrm{Ca}$, and $\mathrm{Mg}$ are intermediate, with relative scatters of $7 \%-$ $14 \%$. That $\mathrm{Ni}$, normally considered immobile, comes in this group may be due more to lava inhomogeneity (different contents of olivine) than to alteration.

The other elements have relative scatters of $6 \%$ or less except for $\mathrm{Y}$, discussed below. These elements include those known to be relatively immobile during alteration ( $\mathrm{Zr}, \mathrm{Nb}, \mathrm{REE}$, in part $\mathrm{Y}$ ), but even $\mathrm{Na}$, commonly mobilized during alteration, falls in this group. A mobility effect for $\mathrm{Na}$ is clearly seen in the $\mathrm{Na}_{2} \mathrm{O}$ diagram in Figure 1. We suspect that the fairly high relative scatter for $\mathrm{Zr}$ is caused by pri- mary inhomogeneity, mainly in some of the siliceous lavas in Site 917 Middle Series. Among the major elements, Si and Al have the lowest relative scatters in accordance with their structural position as framework formers in the minerals.

\section{BEHAVIOR OF YTTRIUM}

The largest difference in correlation coefficients between identical and parallel powders is seen for Y (Table 1). Y is normally considered an immobile element, but if the whole data set is considered, $\mathrm{Y}$ has a relative scatter of $13 \%$, grouping it with the mobile elements $\mathrm{Cu}$ and $\mathrm{Sr}$ (Fig. 2). Figure 3 shows that the $\mathrm{Y}$ scatter for most of the analyzed rocks is actually small (3\%), confirming the general immobility of Y. The exception is the lavas from Site 918, many of which show a very large scatter about the regression line. When some Site 918 samples were cross-checked, the two laboratories obtained similar results for identical powders, so the scatter is geological, not analytical.

The lava flows from Site 918 appear to be no more altered than those from Site 917, which show a much smaller Y scatter. In gener- 
Table 1. Correlation coefficients $(\mathrm{R})$ and regression line slopes $(\mathrm{Sl})$ for analyses made in Edinburgh and Copenhagen.

\begin{tabular}{|c|c|c|c|c|c|c|c|}
\hline & $\mathrm{R}$ (all) & Sl (all) & $\mathrm{R}$ (par) & $\mathrm{Sl}$ (par) & R (id) & Sl (id) & $\mathrm{R}(\mathrm{id})-\mathrm{R}(\mathrm{par})$ \\
\hline $\mathrm{SiO}_{2}$ & 0.9908 & 1.0060 & 0.9884 & 1.0030 & 0.9999 & 1.0149 & 0.0115 \\
\hline $\mathrm{TiO}_{2}$ & 0.9861 & 0.9603 & 0.9853 & 0.9576 & 0.9999 & 0.9896 & 0.0146 \\
\hline $\mathrm{Al}_{2} \mathrm{O}_{3}$ & 0.9616 & 0.9922 & 0.9592 & 0.9931 & 0.9993 & 0.9904 & 0.0401 \\
\hline $\mathrm{FeO}$ & 0.9709 & 0.9836 & 0.9657 & 0.9719 & 0.9998 & 1.0473 & 0.0341 \\
\hline $\mathrm{MnO}$ & 0.8641 & 0.8734 & 0.8499 & 0.8601 & 0.9993 & 1.0000 & 0.1494 \\
\hline $\mathrm{MgO}$ & 0.9501 & 1.0577 & 0.9466 & 1.0590 & 1.0000 & 1.0044 & 0.0534 \\
\hline $\mathrm{CaO}$ & 0.9586 & 1.0377 & 0.9539 & 1.0451 & 1.0000 & 0.9965 & 0.0461 \\
\hline $\mathrm{Na}_{2} \mathrm{O}$ & 0.9668 & 0.9767 & 0.9626 & 0.9812 & 0.9995 & 0.9705 & 0.0369 \\
\hline $\mathrm{K}_{2} \mathrm{O}$ & 0.9838 & 0.9841 & 0.9781 & 0.9724 & 1.0000 & 1.0164 & 0.0219 \\
\hline $\mathrm{P}_{2} \mathrm{O}_{5}$ & 0.9938 & 0.9427 & 0.9927 & 0.9407 & 0.9995 & 0.9421 & 0.0068 \\
\hline $\mathrm{Rb}$ & 0.9697 & 0.9573 & 0.9544 & 0.9340 & 0.9997 & 0.9995 & 0.0453 \\
\hline $\mathrm{Ba}$ & 0.9720 & 0.9175 & 0.9653 & 0.9264 & 0.9996 & 0.8880 & 0.0343 \\
\hline $\mathrm{Sr}$ & 0.9669 & 0.9761 & 0.9614 & 0.9722 & 0.9990 & 1.0009 & 0.0376 \\
\hline $\mathrm{La}$ & 0.9916 & 0.8534 & 0.9903 & 0.8512 & 0.9955 & 0.8347 & 0.0052 \\
\hline $\mathrm{Ce}$ & 0.9926 & 1.0002 & 0.9916 & 0.9960 & 0.9974 & 1.0244 & 0.0058 \\
\hline $\mathrm{Nd}$ & 0.9904 & 0.8972 & 0.9885 & 0.8953 & 0.9954 & 0.9049 & 0.0069 \\
\hline Y & 0.8908 & 1.0200 & 0.8603 & 1.0153 & 0.9979 & 1.0339 & 0.1377 \\
\hline $\mathrm{Zr}$ & 0.9927 & 1.0500 & 0.9906 & 1.0541 & 0.9993 & 1.0334 & 0.0087 \\
\hline $\mathrm{Nb}$ & 0.9986 & 1.0841 & 0.9985 & 1.0860 & 0.9996 & 1.0711 & 0.0010 \\
\hline $\mathrm{Zn}$ & 0.8784 & 0.8550 & 0.8359 & 0.7983 & 0.9773 & 0.9825 & 0.1414 \\
\hline $\mathrm{Cu}$ & 0.9452 & 0.8873 & 0.9315 & 0.8775 & 0.9982 & 0.9350 & 0.0668 \\
\hline Co & 0.9594 & 0.8371 & 0.9567 & 0.9197 & 0.9978 & 0.9354 & 0.0410 \\
\hline $\mathrm{Ni}$ & 0.9966 & 1.0181 & 0.9958 & 1.0072 & 1.0000 & 1.0512 & 0.0042 \\
\hline $\mathrm{Sc}$ & 0.9845 & 0.8129 & 0.9834 & 0.8145 & 0.9903 & 0.8128 & 0.0069 \\
\hline V & 0.9792 & 0.9192 & 0.9750 & 0.9158 & 0.9975 & 0.9630 & 0.0226 \\
\hline $\mathrm{Cr}$ & 0.9962 & 0.9945 & 0.9956 & 0.9836 & 0.9997 & 1.0384 & 0.0041 \\
\hline $\mathrm{Ga}$ & 0.8933 & 0.9705 & 0.8875 & 0.9722 & 0.9115 & 0.9074 & 0.0240 \\
\hline
\end{tabular}

Notes: all = total data set; par = parallel powders; id = identical powders. The last column is the difference between the correlation coefficients for the identical and parallel powders. Larger R(id) - R(par) indicate larger data scatter for the parallel powders than for the identical powders.

Figure 2. Differences in relative errors $(\Delta \mathrm{re})$ for the various elements, as explained in Table 2. $\Delta$ re for an element is the difference between the relative errors for the parallel powder set and the identical powder set. Elements with high $\Delta$ re show a much larger scatter for the parallel powders compared with the identical powders, interpreted as mainly due to element redistribution during secondary alteration, with a minor component of lava inhomogeneity. The elements are arranged in order of increasing $\Delta$ re (increasing mobility) from left to right, excluding the Site 918 lavas. The unusual behavior of Y in the Site 918 lavas is discussed in the text.

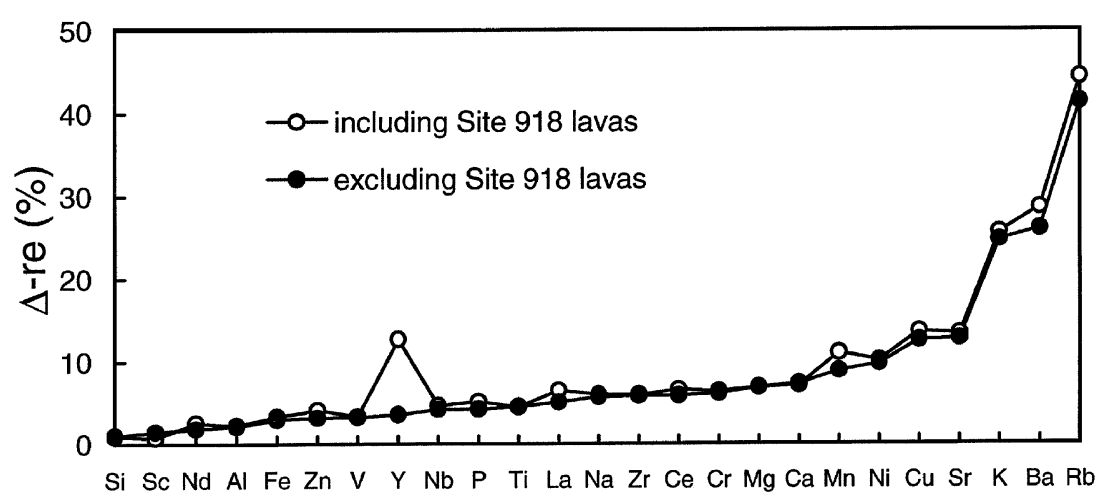

al, the samples from Site 918 have smaller contents of $\mathrm{H}_{2} \mathrm{O}$ (average $2.0 \%$ ) than those from Site 917, where the Upper Series has an average of $4.4 \% \mathrm{H}_{2} \mathrm{O}$. The $\mathrm{CO}_{2}$ contents in both groups are uniformly low, mostly $<0.1 \%$ (L.M. Larsen et al., this volume). There is no correlation between $\mathrm{Y}$ loss or gain and the volatile contents. There is, however, a difference in alteration style between the two sites, as noted earlier. The rocks from Site 917 may show extensive breakdown of plagioclase but not of clinopyroxene, whereas the rocks from Site 918 may show extensive breakdown of clinopyroxene with plagioclase still being relatively fresh. The breakdown of clinopyroxene is most probably the reason that some of the most altered samples from Site 918 (units 6,11.1, 17, and 18) have lost Ca (up to more than $50 \%$ ), whereas there is no distinguishable Ca loss in even the most altered samples in Site 917. Ca does not show any large deviations in Figure 2 because the parallel samples of the leached flows are nearly equally depleted in $\mathrm{Ca}$.

The breakdown of clinopyroxene at Site 918 is probably also the reason for the release of $\mathrm{Y}$, which resides preferentially in this mineral. Samples that have lost $\mathrm{Ca}$ have either lost or gained Y. Some samples with no discernible Ca loss have gained $\mathrm{Y}$ but none have lost $\mathrm{Y}$. The indication is that $\mathrm{Y}$ is released together with $\mathrm{Ca}$ and is reprecipitated over a scale larger than a sample (about $4 \mathrm{~cm}$ ) while $\mathrm{Ca}$ is lost. Because $\mathrm{Y}$ is present in trace concentrations it is not possible to identify the $\mathrm{Y}$-accommodating secondary mineral by petrography or bulk chemical analysis.

$\mathrm{Sc}$ and the rare earth elements (REE) also reside preferentially in clinopyroxene in basalts. There is a tendency for the most altered samples at Site 918 to have higher Sc than the less altered, but generally Sc appears to be fixed on a scale smaller than a sample. The heavy REE have many properties in common with Y. It is not possible to determine whether the heavy REE have also been mobilized in the Site 918 lavas because the most altered samples have not been analyzed by neutron activation (Fitton et al., Chap. 28, this volume). However, Figure 2 indicates that the light REE (La, Ce, Nd) may be slightly affected by the alteration, though far less than Y. Mn is clearly also affected; this element is known to be mobile and will be released during decomposition of both olivine and clinopyroxene.

A few cases of Y mobility during seafloor weathering have been described earlier. Morton and Knox (1990) noted a large range in Y (11-100 ppm) in altered tephras from the North Sea. Zuleger et al. (1995) described highly altered patches with low Y, Ca, Ti, Zr, and REE in greenschist-facies sheeted dikes south of the Costa Rica Rift, but favored a primary igneous origin for the element variations. Bienvenu et al.(1990) and Allan and Gorton (1992) described Y loss during alteration of lavas from the Japan Sea. Allan and Gorton (1992) noted Y contents of 14-23 ppm within a single igneous unit, 
Table 2. Differences in relative errors ( $\Delta$ re) for analyses made in Edinburgh and Copenhagen.

\begin{tabular}{lcc}
\hline & \multicolumn{2}{c}{$\Delta$ re } \\
\cline { 2 - 3 } Element & excl. Site 918 & incl. Site 918 \\
\hline $\mathrm{SiO}_{2}$ & 1.036 & 0.930 \\
$\mathrm{Sc}$ & 1.470 & 0.736 \\
$\mathrm{Nd}$ & 1.808 & 2.550 \\
$\mathrm{Al}_{2} \mathrm{O}_{3}$ & 2.123 & 2.252 \\
$\mathrm{FeO}_{\text {tot }}$ & 2.963 & 3.294 \\
$\mathrm{Zn}$ & 3.163 & 4.112 \\
$\mathrm{~V}$ & 3.267 & 3.331 \\
$\mathrm{Y}$ & 3.579 & 12.716 \\
$\mathrm{Nb}$ & 4.229 & 5.116 \\
$\mathrm{P}_{2} \mathrm{O}_{5}$ & 4.229 & 5.116 \\
$\mathrm{TiO}$ & 4.485 & 4.457 \\
$\mathrm{La}$ & 5.041 & 6.490 \\
$\mathrm{Na}$ & 5.676 & 5.961 \\
$\mathrm{Zr}$ & 5.814 & 5.932 \\
$\mathrm{Ce}$ & 5.834 & 6.564 \\
$\mathrm{Cr}$ & 6.084 & 6.409 \\
$\mathrm{MgO}$ & 6.870 & 6.809 \\
$\mathrm{CaO}$ & 7.303 & 7.107 \\
$\mathrm{MnO}$ & 8.845 & 10.997 \\
$\mathrm{Ni}$ & 9.690 & 10.132 \\
$\mathrm{Cu}$ & 12.562 & 13.619 \\
$\mathrm{Sr}$ & 12.751 & 13.292 \\
$\mathrm{~K}_{2} \mathrm{O}$ & 24.692 & 25.620 \\
$\mathrm{Ba}$ & 26.024 & 28.621 \\
$\mathrm{Rb}$ & 41.350 & 44.322 \\
& & \\
& &
\end{tabular}

Notes: The figures were calculated as follows. The standard error is calculated with the "STEYX" function in the Excel computer program. The relative error is the standard error expressed as a percentage of the average concentration of an element, and $\Delta \mathrm{re}$ for an element is the difference between the relative errors for the parallel powder set and the identical powder set. The two columns are calculated with exclusion (excl.) and inclusion (incl.) of the data for Site 918.

negatively correlated with loss on ignition. Taylor et al. (1992) described lavas from the Izu-Bonin forearc basin and noted local redistribution of $\mathrm{P}, \mathrm{Y}$, and REE in massive lithologies but not in more porous lithologies (breccias); this was ascribed to more efficient fluid flow through the more permeable rocks.

In the Site 918 succession, the mobility of $\mathrm{Y}$ is related to the breakdown of clinopyroxene, and there is no correlation between $\mathrm{Y}$ and the volatile content. Differences in Y contents within a lava unit are as large as 18-37 ppm for Unit 918-17. The preferential breakdown of clinopyroxene before plagioclase will occur when the hydrothermal fluids have a very low temperature, whereas fluids at somewhat higher temperatures will lead to breakdown of plagioclase before clinopyroxene (P.S. Neuhoff, pers. comm., 1996). The different alteration styles at Sites 918 and 917 therefore may be caused by lower temperatures of the hydrothermal fluids at Site 918 than at Site 917. The low $\mathrm{CO}_{2}$ contents in the lavas at the southeast Greenland Margin suggest that the alteration took place before the succession was submerged below sea level.

\section{CONCLUSIONS}

The lava succession at the southeast Greenland Margin was sampled and analyzed in XRF laboratories in Edinburgh and Copenhagen. Results for identical powders are generally in excellent agreement. Results for parallel powders (from neighboring samples in the same lava units), while in good agreement, show clearly the scattering effects of secondary alteration, and, to a lesser extent, primary lava inhomogeneity. The elements can be ranked according to the amount of scatter produced by the alteration, with $\mathrm{Ba}, \mathrm{Rb}$, and $\mathrm{K}$ as the most mobile, and $\mathrm{Si}, \mathrm{Sc}, \mathrm{Al}, \mathrm{Fe}, \mathrm{Zn}, \mathrm{V}$, and $\mathrm{Nb}$ as the least mobile elements. The parallel sampling procedure has revealed that $\mathrm{Y}$ was mobile during alteration at Site 918 . This is ascribed to preferential

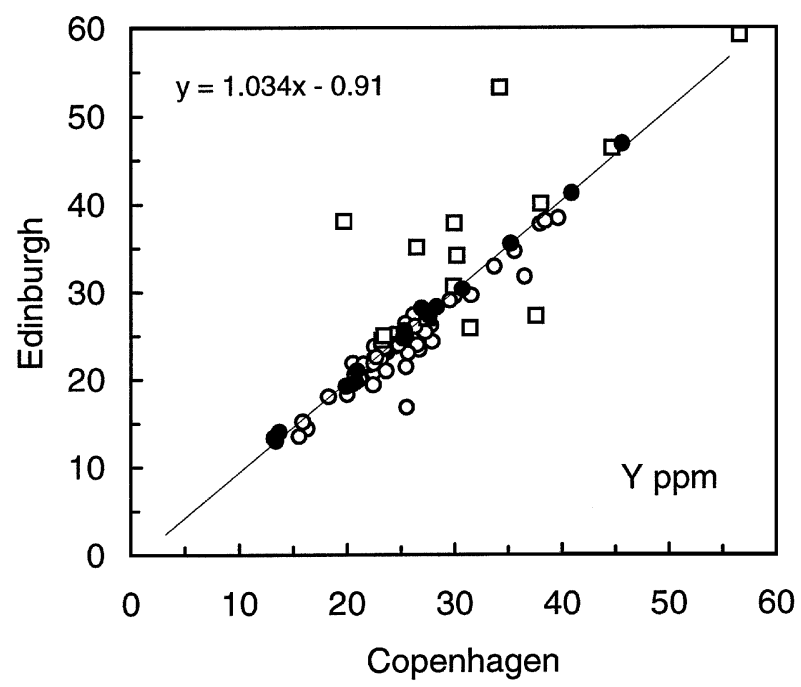

Figure 3. Y analyses in Edinburgh and Copenhagen. The regression line and equation include only the identical powders. Solid circles = identical powders; open circles $=$ Site 917 parallel powders; open squares $=$ Site 918 parallel powders. Note the large data scatter for Y in the Site 918 samples, in contrast to all the other samples.

breakdown of clinopyroxene at Site 918, suggesting lower alteration temperatures for Site 918 than for Site 917.

\section{ACKNOWLEDGMENTS}

We are grateful to Alain Demant for mineralogical and petrographic information on the Site 918 rocks, and to Phil S. Neuhoff for discussions on hydrothermal alteration. The paper is published with the permission of the Geological Survey of Denmark and Greenland.

\section{REFERENCES}

Allan, J.F., and Gorton, M.P., 1992. Geochemistry of igneous rocks from Legs 127 and 128, Sea of Japan. In Tamaki, K., Suyehiro, K., Allan, J., McWilliams, M., et al., Proc. ODP, Sci. Results, 127/128 (Pt. 2): College Station, TX (Ocean Drilling Program), 905-929.

Bienvenu, P., Bougault, H., Joron, J.L., Treuil, M., and Dmitriev, L., 1990. MORB alteration: rare-earth element/non-rare-earth hygromagmaphile element fractionation. Chem. Geol., 82:1-14.

Larsen, H.C., Saunders, A.D., Clift, P.D., et al., 1994. Proc. ODP, Init. Repts., 152: College Station, TX (Ocean Drilling Program).

Morton, A.C., and Knox, R.W.O., 1990. Geochemistry of late Palaeocene and early Eocene tephras from the North Sea Basin. J. Geol. Soc., London, 147:425-437.

Taylor, R.N., Lapierre, H., Vidal, P., Nesbitt, R.W., and Croudace, I.W., 1992. Igneous geochemistry and petrogenesis of the Izu-Bonin forearc basin. In Taylor, B., Fujioka, K., et al., Proc. ODP, Sci. Results, 126: College Station, TX (Ocean Drilling Program), 405-430.

Zuleger, E., Alt, J.C., and Erzinger, J.A., 1995. Primary and secondary variations in major and trace element geochemistry of the lower sheeted dike complex: Hole 504B, Leg 140. In Erzinger, J., Becker, K., Dick, H.J.B., and Stokking, L.B. (Eds.), Proc. ODP, Sci. Results, 137/140: College Station, TX (Ocean Drilling Program), 65-80.

Date of initial receipt: 6 November 1995

Date of acceptance: 3 July 1996

Ms 152SR-246 